\title{
Attitudes towards and beliefs about schizophrenia in Xhosa families with affected probands
}

\author{
NI Mbanga, Dipl Nurs Admin, Department of Psychiatry, University of Stellenbosch \\ DJH Niehaus, MMed Psych, Department of Psychiatry, University of Stellenbosch \\ NC Mzamo, Dipl Nurs, Department of Psychiatry, University of Stellenbosch \\ CJ Wessels, BA Hons, Department of Psychiatry, University of Stellenbosch \\ A Allen LLB, MA, Department of Psychology, Edith Cowan University \\ RA Emsley, MMed Psych, MD, Department of Psychiatry, University of Stellenbosch \\ DJ Stein, FRCPC, Department of Psychiatry,University of Stellenbosch
}

\section{Abstract}

Objective: The development of effective psychoeducational programs for the management of schizophrenia requires an understanding of attitudes towards and beliefs about the disorder in families of affected probands. In order to establish the need for adaptation of Western psychoeducational programs, these variables were investigated in Xhosa speaking families in South Africa

Design: Xhosa speaking family members of patients with DSM-IV schizophrenia were recruited on a voluntary basis, and interviewed with a structured belief and attitudes questionnaire adapted from previous studies in the West.

Setting: The study population was drawn from both urban and rural Xhosa communities in South Africa.

Subjects: 100 Xhosa speaking family members participated in the study.

Results: Family members most often recommended treatment with psychotropic medications (88\%) and traditional healers $(32 \%)$, and least often recommended psychotherapy (4\%) and meditation (1\%). Of the respondents who recommended traditional healing methods, $92 \%$ also recommended simultaneous use of allopathic treatment.

Conclusion: Attitudes towards and beliefs about schizophrenia in family members of patients with schizophrenia may differ substantially from those described in previous work in the West. An understanding of local attitudes and beliefs is crucial for the successful development of local psychoeducational programs.

\section{Abstrak}

Doelwit: Ten einde suksesvolle psigo-opvoedkundige programme op te stel, moet die familie van die pasient se houding jeens en die begrip van die geestessiekte bekend wees. Die houding jeens en geloof oor skisofrenie is ondersoek in Xhosa sprekende individue in Suid Afrika ten einde vas te stel of die bestaande Westerse programme gewysig behoort te word.

Studie ontwerp: Xhosa sprekende familie lede van pasient met skisofrenie (DSM-IV) het vrywillig deelgeneem aan die studie. "n Gestruktureerde vraelys (aangepas vanuit vorige Westerse studies) oor houdings jeens en begrip van skisofrenie is deur elke deelnemer voltooi.

Studie opset: Die studie populasie is afkomstig van beide stedelike en plattelandse Xhosa gemeenskappe in Suid Afrika.

Deelnemers: 100 Xhosa sprekende familie lede het deelgeneem.

Resultate: Psigotrope medikasie (88\%) en tradisionele genesers $(32 \%)$ was die mees algemene voorstelle vir behandeling van skisofrenie, terwyl psigoterapie (4\%) en meditasie $(1 \%)$ nie veel steun geniet nie. Persone wat tradisionele genesing aanbeveel het, was ook geneig om die gelyktydige gebruik van allopatiese behandeling aan te beveel $(92 \%)$.

Samevatting: Die houding jeens en begrip van skisofrenie verskil beduidend van dié in vorige Westerse studies. Aandag behoort gegee te word aan die inhoud van Westerse psigo-opvoedkundige programme voordat dit geïnisieer word in Suid Afrika 


\section{Introduction}

Schizophrenia is a prevalent and chronic disorder, which is accompanied by substantial impairment in function. The total costs of this disorder, comprising both direct costs of treatment and indirect costs of dysfunction, are therefore extremely high. Indeed, it has been estimated that in the United States, the treatment of patients with schizophrenia consumes $2.5 \%$ of the annual total health care allocations (Meltzer, 1999:3).

Fortunately, there have been important advances in the management of schizophrenia in recent decades. These include the introduction of novel psychopharmacological agents, as well as the use of psychosocial interventions. Psychoeducational programs are increasingly used, with a growing recognition that family members of patients with schizophrenia may play a useful role in helping to prevent relapse (Goldstein, 1995:59).

The development of successful psychoeducational programs must be based on an understanding of existing attitudes towards and beliefs about disease. A number of studies document widespread misconceptions about the etiology and treatment of this disorder in the lay community (Angermeyer et al, 1993:114; Angermeyer and Matschinger, 1994:39; Angermeyer and Matschinger, 1996:199; Wahass \& Kent. 1997:175; Jorm et al, 1997:143; Jorm et al, 1997:182). Attending to patients and family members' explanatory models of disease (Kleinman, 1988), and education in order to change misconceptions (Becker, 1975:10), may prove useful in destigmatizing schizophrenia and in improving compliance with treatment.

A recent set of studies in Germany (Angermeyer et al, 1993:114; Angermeyer and Matschinger, 1994:39; Angermeyer and Matschinger, 1996:199), for example, found that laypersons regard schizophrenia as caused mainly by psychosocial stressors, biological factors and intra-psychic factors. The treatment options most favored were «talking it over» $(>75 \%)$, relaxation $(>50 \%)$ and psychotherapy $(>50 \%)$. Psychotropic drugs were recommended by less than $25 \%$ of the lay public. These results reinforce the need for psychoeducation, and for focusing on information about pharmacological interventions.

Similarly, in South Africa local beliefs about the causes and treatment of schizophrenia help determine health-seeking pathways and may be an important locus for psychoeducational intervention. Certainly, anecdotal impressions would indicate a strong belief in supernatural causes of illness, and a reliance on traditional healers for its treatment (Buhrmann, 1982:163; Buhrmann, 1984). This study aims to elicit the attitudes towards and beliefs about schizophrenia in family members of affected probands.

\section{Methods}

Patients with schizophrenia were voluntarily recruited from inand outpatient services in the urban areas of the Western Cape and the rural areas of the Eastern Cape in South Africa, as part of a larger genetics study. Potential subjects had to be of Xhosa ethnicity (all of the grandparents of Xhosa origin). Mental health workers identified possible participants, and candidates were then screened for suitability after obtaining written informed consent. They were diagnosed on the basis of DSM-IV criteria using a structured clinical interview, the Diagnostics Interview for Genetics Studies (DIGS) (APA, 1994). The study population was comprised of 100 Xhosa speaking family members of these probands.

One caregiver or close family member who voluntarily agreed to take part in the study was interviewed by a trained psychiatric nurse who visited the family at home and administered a structured questionnaire. This questionnaire (English version) was based on the work of Angermeyer and Matshinger et al (Angermeyer et al, 1993:114; Angermeyer and Matschinger, 1994:39; Angermeyer and Matschinger, 1996:199) in Germany. It allowed for yes, no or unsure responses and focused on respondents' views of the causes ( 17 options, multiple choices possiblc [Table 1]), treatment (9 possible options, multiple choices allowed [Table 2]), and course of schizophrenia (chronic versus curable, need for continued medication use and compliance). The role of traditional healing methods was assessed by means of the addition of two options to the treatment section, namely the use of traditional healers' services and traditional rituals.

\section{Results}

One hundred Xhosa family members participated in the study. $76 \%$ of the study population was female. Mean age $( \pm$ SD) of the participants was 61.1 ( \pm 13.0 ) years (range 24-87). The mean level of scholastic achievement was $6.0( \pm 3.5)$ years, with only $2 \%$ of participants having completed high school. Subjects were mostly commonly mothers $(59.2 \%)$ or fathers $(21.4 \%)$ of probands with schizophrenia.

Respondents ascribed the development of schizophrenia to different causes (Table 1). The most common causes noted were witchcraft or possession by evil spirits $(67 \%)$, brain disease (46\%) and a stressful life event (38\%). The least common causes documented were unconscious conflict (3\%), loss of natural ways of life (3\%) and signs of the Zodiac (2\%). When compared with the «average person», family members stated that probands were more dirty $(52 \%)$, weak (48\%), unpredictable $(45 \%)$. dangerous $(44 \%)$, delicate $(41 \%)$ or foolish $(39 \%)$.

Respondents most commonly recommended treatment with psychotropic medications ( $88 \%)$, traditional healer's methods (32\%) and rituals (30\%). Psychotherapy (4\%) and meditation (1\%) were the treatment methods least often recommended (Table 2 ). Most family members (63\%) became concerned when probands discontinued medication for a month, with some $(32 \%)$ becoming worried after a week of noncompliance.

Forty-one percent of respondents believed that the natural course of schizophrenia is one of remissions with the possibility of relapse, while $24.2 \%$ believed that the disorder can be cured without medication. $28 \%$ of respondents stated that if optimal treatment is given then cure is possible, with $30.3 \%$ holding that optimal treatment led to remission with the possibility of relapse. 


\section{Discussion}

Our findings indicate that in a Xhosa speaking sample witchcraft or possession by evil spirits was the most commonly endorsed view of the cause of illness. This view differs markedly from that found in a series of studies in German (Angermeyer et al, 1993:114; Angermeyer and Matschinger, 1994:39; Angermeyer and Matschinger, 1996:199) where psychosocial stressors, biological factors, and intra-psychic factors were the most commonly believed causes of schizophrenia. and from similar sets of findings in other Westernized cul-
Laypersons' explanatory models of disease are of course intimately related to cultural beliefs. The Xhosa belief system includes an acceptance of the phenomena of witchcraft and possession by evil spirits, and the notion that ancestors play an important role in protecting the community from such spirits (Buhrmann, 1982:163; Buhrmann, 1984; Tshotsho \& Strumpher, 1996:63-66). The ancestors require appeasement with rituals, and neglecting such rituals is held to lead to withdrawal of ancestral protection and the possible onset of mental illness. Thus it is not surprising that respondents emphasized the role of witchcraft and evil spirits in the etiology of schizo-

\section{Table 1 : Perceived Causes of Schizophrenia (Percentages)}

\begin{tabular}{|c|c|c|c|}
\hline & YES & NO & UNSLRE \\
\hline Family relationship problems & 14 & 55 & 31 \\
\hline Work difficulties & 13 & 68 & 19 \\
\hline Stressful events & 38 & 40 & 22 \\
\hline Brain disease & 46 & 41 & 13 \\
\hline Heredity & 34 & 50 & 16 \\
\hline Lack of will power & 10 & 72 & 18 \\
\hline Expecting too much of oneself & 14 & 82 & 4 \\
\hline Unconscious conflicts & 3 & 84 & 13 \\
\hline Being brought up in a broken home & 25 & 59 & 16 \\
\hline Lack of parental affection & 31 & 54 & 15 \\
\hline Over protective parents & 19 & 75 & 6 \\
\hline Loss of traditional values & 29 & 56 & 15 \\
\hline Loss of a natural way of life & 3 & 84 & 13 \\
\hline Will of God & 31 & 49 & 20 \\
\hline Witchcraft. evil spirits & 67 & 18 & 15 \\
\hline Being poisoned & 37 & 48 & 15 \\
\hline Signs of the Zodiac & 2 & 52 & 46 \\
\hline
\end{tabular}

tures (Wahass \& Kent. 1997:175; Jorm et al, 1997:143; Jorm et al, 1997:182). Similarly, Xhosa family members most commonly supported psychotropic medications and traditional healing methods (for example, rituals such as beer brewing and the slaughter of cattle), in contradiction to the more negative perceptions of medication in Westernized cultures (Angermeyer et al, 1993:114; Angermeyer and Matschinger, 1994:39; Angermeyer and Matschinger, 1996:199; Wahass \& Kent. 1997:175; Jorm et al, 1997:143; Jorm et al, 1997:182). phrenia, and the role of traditional rituals in its treatment. Nevertheless, several other causes and treatments of schizophrenia were listed by respondents, indicating the complexity of explanatory models in this community. Endorsement of stressful life-events (38\%), broken homes (25\%) and lack of parental affection (31\%) as causes of schizophrenia is reminiscent of Western lay and biomedical explanatory models of the disorder (3-8). Similarly, not only was psychotropic medication the most commonly recommended form of treatment, but 
the vast majority of respondents supporting traditional healers also supported the simultaneous use of psychotropic medication.

Indeed, our impression was that respondents' explanatory models of schizophrenia relied on multiple theories and observations. Many felt that traditional healers' methods protected individuals from invasion by «bad spirits», but that Western treatments prevented the symptoms from getting worse. The often being treated with depot preparations).

A number of important limitations of this study deserve emphasis. Family members were relatively elderly and poorly educated; findings are unlikely to be readily generalizable to younger more educated respondents. This is partly reflected by the number of «unsure» responses to concepts such a meditation, signs of the zodiac and even psychotherapy. Furthermore, the fact that interviewers were nurses may have biased

\section{Table 2: Preferred treatment methods}

\begin{tabular}{|l|l|l|l|}
\hline & Yes & No & Unsure \\
\hline Relavation & 5 & 84 & 11 \\
\hline Pull oneself together & 6 & 82 & 12 \\
\hline Talk it over & 7 & 87 & 6 \\
\hline Nature will cure it & 2 & 91 & 7 \\
\hline Meditation & 1 & 55 & 44 \\
\hline Pșchotherapy & 4 & 56 & 40 \\
\hline Psychotropic meditations & 88 & 5 & 7 \\
\hline Traditional healer & 32 & 58 & 10 \\
\hline Traditional rituals & 30 & 61 & 9 \\
\hline
\end{tabular}

use of multiple models and interventions can arguably be seen as representing a flexible and pragmatic response to the occurrence of a serious medical disorder.

A number of worrying perceptions were noted in respondents. Overall, there was only partial support for a biomedical model of schizophrenia as a disease of the brain, with $46 \%$ of respondents endorsing this opinion, but $42 \%$ believing the opposite. Similarly, patients were to some extent stigmatized as dirty, unpredictable, and dangerous.

Furthermore, $28 \%$ of respondents believed that schizophrenia can be cured by treatment, a belief that is likely to be overoptimistic. Non-compliance was only seen as a problem one month after medication discontinuation (although this may partly be explained by the fact that probands in this study were respondents away from endorsing traditional beliefs and towards endorsing the importance of psychotropic medication. Nevertheless, our impression was that respondents were open and frank about their agreements and disagreements with the standard biomedical model. Clinicians who work with Xhosa speaking patients with schizophrenia and their families would do well to be aware of traditional attitudes and beliefs towards this illness, and to make an effort to determine their explanatory models. Psychoeducational programs need to address such explanatory models, and clinicians need to negotiate a shared biomedical model (Kleinman, 1988; Becker and Maiman, 1975; Stein, 1993:322-329). Such a negotiation is likely to promote to foster the therapeutic alliance and to promote adherence to treatment. 


\section{References}

AMERICAN PSYCHIATRIC ASSOCIATION 1994: The Diagnostic and Statistical Manual of Mental Disorders, Fourth edition. Washington, DC: American Psychiatric Press

BECKER MH \& MAIMAN LA 1975: Sociobehavioral determinants of compliance with health and medical care recommendations. Medical Care. 13:10-24

BUHRMANN MV 1982: The Xhosa healers of Southern Africa. Journal Analitical Psvchology. 27: 163-173

BUHRMAN MV 1984: Living in two worlds. Cape Town: Human \& Rosseau, 12, 35.

ANGERMEYER MC,DAUMER R, MATSCHINGER H 1993: Benefits and risks of psychotropic medications in the eyes of the general public: Results of a survey in the Federal Republic of Germany. Pharmacopsvchiatry. 26: 114-120

ANGERMEYER MC \& MATSCHINGER H. 1994: Lay beliefs about schizophrenic disorder: the results of a population survey in Germany. Acta Psvchiatrica Scandinavica. 89: 39-45

ANGERMEYER MC \& MATSCHINGER H 1996: Relatives' beliefs about the causes of schizophrenia. Acta Psvchiatrica Scandinavica. 93: 199-204

GOLDSTEIN MJ 1995: Psychoeducation and relapse prevention. International Clinical Psychopharmacology. 9 (S5): $59-69$

JORM AF, KORTEN AE, JACOMB PA, CHRISTENSEN H, RODGERS B, POLLITT P 1997: Public beliefs about causes and risk factors for depression and schizophrenia. Social Psvchiatry and Psvchiatric Epidemiology. 32:143-148

JORM AF, KORTEN AE, JACOMB PA, CHRISTENSEN H, RODGERS B, POLLITT P 1997: Mental health literacy»: a survey of the public's ability to recognise mental disorders and their beliefs about the effectiveness of treatment. Medical Journal of Australia. 166: 182-186

KLEINMAN A 1988: Rethinking Psychiatry: From Cultural Category to Personal Experience. New York, Free Press

MELTZER HY 1999: Outcome in schizophrenia: beyond symptom reduction. Journal of Clinical Psvchiatry. 60 (S3): 3-7

TSHOTSHO MNZ \& STRUMPHER J 1996: Assessment of a Xhosa psychiatric patient using the transcultural approach. Curationis. 19: 63-66

WAHASS S \& KENT G 1997: A comparison of public attitudes in Britain and Saudi Arabia towards auditory hallucinations. International Journal of Social Psychiatry. 43: 175-183

STEIN DJ 1993: Cross-cultural psychiatry and the DSM-IV. Comprehensive Psvchiatrv. 34: 322-329 